\title{
Wheat (Triticum aestivum L.) Reaction to New Bifunctional Carbamate Compounds
}

\author{
Antonida V. Kalistratova ${ }^{1}$, Maxim S. Oshchepkov ${ }^{1}$, Maria S. Ivanova ${ }^{1}$, Leonid V. Kovalenko ${ }^{1}$, \\ Marina A. Tsvetikova ${ }^{2}$, Nataliya A. Bystrova ${ }^{2} \&$ Konstantin A. Kochetkov ${ }^{2}$ \\ ${ }^{1}$ D. I. Mendeleev University of Chemical Technology of Russia, Moscow, Russia \\ ${ }^{2}$ A. N. Nesmeyanov Institute of Organoelement Compounds of Russian Academy Sciences, Moscow, Russia \\ Correspondence: Maxim S. Oshchepkov, D. I. Mendeleev University of Chemical Technology of Russia, \\ Miusskaya pl. 9, Moscow, 125047, Russia. E-mail: maxim.os@mail.ru
}

Konstantin A. Kochetkov, A. N. Nesmeyanov Institute Organoelement Compounds of Russian Academy Sciences, Vavilov st., 28, Moscow, 119991, Russia. E-mail: const@ineos.ac.ru

Received: May 18, 2021

doi:10.5539/jas.v13n9p36
Accepted: July 17, $2021 \quad$ Online Published: August 15, 2021

URL: https://doi.org/10.5539/jas.v13n9p36

This study was supported by the Ministry of Science and Higher Education of the Russian Federation, using scientific equipment of the Center for the Study of the Structure of Molecules at INEOS RAS (Institute of Organoelement Compounds of the Russian Academy of Sciences), Russian Foundation for Basic Research, grant № 19-03-00492 and was awarded with silver medal and diploma at the Moscow International Salon of Inventions and Innovative Technologies "Archimedes-2020" (Bystrova, 2020).

\begin{abstract}
Extreme environmental conditions increase the risk of abiotic stresses in plants, which reduce productivity of land. The investigation and developmentof synthetic approach to new antistress compounds, increasing the resistance of plants to negative factors, are relevant to the present. The objective of this study was to synthesize and to test the effect of a series of new carbamate and oxamate plant growth regulators on early vegetation processes of wheat (Triticum aestivum L.). Three independent series of experiments were conducted using lipophilic compounds N-(2,4-Dimethylphenyl)-N'-i-propoxycarbonylaminoethylurea (1) and O-Isopropyl-N-[2-(4-methylphenylaminocarbonyloxy)etyl]oxamate (2) and water-soluble compounds O-i-Propyl-N-(2-hydroxyethylamino)carbamate (3) and O-i-Propyl-N-(2-hydroxyethyl)oxamate (4). Strong stimulating effect on shoots and roots growth in the wheat was found for all studied compounds in all experiments. The highest germination rate (89.6-96.3\%) was registered for compound 4 . The use of the studied substances 1, 3 and 4 in all cases leads to significant increase in the Seedling Vigor Index (SVI). The high energy index of compounds 3 and 4 can lead to increased photosynthesis and, as a result, to an increase in crop yield. Based on the data obtained on the values of relative water content (RWC) indicators and their components, it can be assumed that all plants after treatment with substances 1-4 are able to tolerate unfavorable weather phenomena. Experimental results show that the percentage of plant recovery after resuming watering was $84-100 \%$. Thus, the data obtained indicate that the synthesized compounds exhibit antistress and growth regulatory activity.
\end{abstract}

Keywords: synthetic plant growth regulators, carbamates, oxamates, germination, seedling growth, seedling vigor index

\section{Introduction}

The global change of environment is one of the main problems of the last century (Raza et al., 2019) and, according to forecasts of the Food and Agriculture Organization of the United Nations, by the end of this century, along with the increasing average temperature, crop production will be dramatically decreasing worldwide (Ito et al., 2018; Rogelj et al., 2016). Indeed, continuous droughts, heavy rains, temperature fluctuations, soil salinization and insect pests drastically lower agricultural productivity (Dhankher \& Foyer, 2018). The use of plant growth regulators improves resistance to extreme conditions and mitigates the effects of stress on plants (Chauhan et al., 2019; Sosnowski et al., 2017). 
Wheat is the main grain crop, occupying about $40 \%$ of agricultural areas in the world (FAOSTAT, 2017) and its production is directly dependent on the environment conditions (Asseng et al., 2015). In this regard, drought and sharp temperature changes are the key stress factors affecting crop productivity (Hatfield \& Prueger, 2015): strong temperature drop leads to sterility, while dehydration adversely affects the morphology and physiology of plants (Barlow et al., 2015; Salehi-Lisar \& Bakhshayeshan-Agdam, 2016). Unfavorable environmental conditions increase the risk of abiotic stresses in plants (Thornton et al., 2014) and reduce productivity of land (Tebaldi \& Lobell, 2018). The investigation and design of new antistress drugs, increasing the resistance of plants to negative factors, are quite relevant today.

In order to overcome the consequences of global environmental changes, farmers diversify crop rotation (Peltonen-Sainio et al., 2020), use insecticides, fungicides and plant growth regulators (PGR), which include chlormequat chloride (CCC), affecting the height of plants, lodging and yield of crops (Finch et al., 2014; Brinkman et al., 2014). In Russia, efforts to create plant growth regulators were initiated as early as the in the 1970's. Over the past years, synthetic PGR with a wide range of biological activity have been created, enhancing the productivity of cultivated plants due to the structural similarity to natural plant hormones, which increases their resistance to a complex of adverse environmental factors (Razina et al., 2018; Oshchepkov et al., 2020).

One of such PGR is Cartolin-2 or N-(isopropoxycarbonyl)-O-(4-chlorophenylcarbamoyl)ethanolamine, a compound with antistress activity that enhances the resistance of plants, particularly wheat, to various adverse conditions: drought, low temperatures, salinization and pathogenic fungi. It accelerates plant growth and the progression of phenophases and promotes biomass accumulation through the activation of protein, carbohydratesand chlorophyll biosynthesis. During droughts it has a protective effect on the photosynthetic apparatus of plant leaves, increases the activity of RNA polymerase and the fraction of the polysome in the ribosom complex (Shapovalov \& Zubkova, 2003). However, the synthesis methodof this compound includes the use of toxic phosgene (Patent SU, 1992), which imposes serious restrictions on the organization of its production.

Earlier we reported (Oshchepkov et al., 2020) that substances structurally similar to compound 1 demonstrate a protective effect against herbicides with hormonal and antimetabolic mechanisms of action and, therefore, they can be used to increase the selectivity of herbicides and for growing crops on soils contaminated with herbicides. Therefore, intensive investigation and testing of biological activity of new analogues of PGR, whose synthesis method is safer and easier to implement technologically (Oshchepkov et al., 2020) are in high demand. Previously, for compounds of the same class, we carried out preliminary tests on tobacco cell culture (growth tests under controlled conditions) and showed that tested compounds have an evident, although multidirectional effect on the metabolic processes (Kovalenko et al., 2020). The objective of this study was to synthesize and test the activity of new carbamate and oxamate plant growth regulators on early vegetation processes of wheat (Triticum aestivum L.).

\section{Materials and Methods}

The experiments were conducted at the laboratories of the Nesmeyanov Institute of Organoelement Compounds of Russian Academy Sciences, Moscow, Russia from September 2020 to August 2021. The geographic coordinates of the site are $55^{\circ} 42^{\prime} 0.3^{\prime \prime} \mathrm{N} ; 37^{\circ} 34^{\prime} 30^{\prime \prime} \mathrm{E}$.

\subsection{Synthesis of Target Plant Growth Regulators 1-4}

The synthesis of carbamates $(1,2)$ and oxamates $(3,4)$ was carried out at the Department of Chemistry and Technology of Biomedical Preparations of Mendeleev University of Chemical Technology of Russia $\left(55^{\circ} 46^{\prime} 44^{\prime \prime} \mathrm{N}\right.$; $\left.37^{\circ} 35^{\prime} 43^{\prime \prime} \mathrm{E}\right)$, Figure 1 . The application of compounds 3,4 is determined by their good solubility in water and ease of penetration through cell membranes. Compounds 1,2 are more lipophilic, which may result in a certain change in the nature of the distribution of these substances in plants and, consequently, a changed activity profile. However, it was expected that the lipophilic aromatic group in compounds 1 and 2 could be easily removed in a different cell location in plant tissues as a result of hydrolysis. 

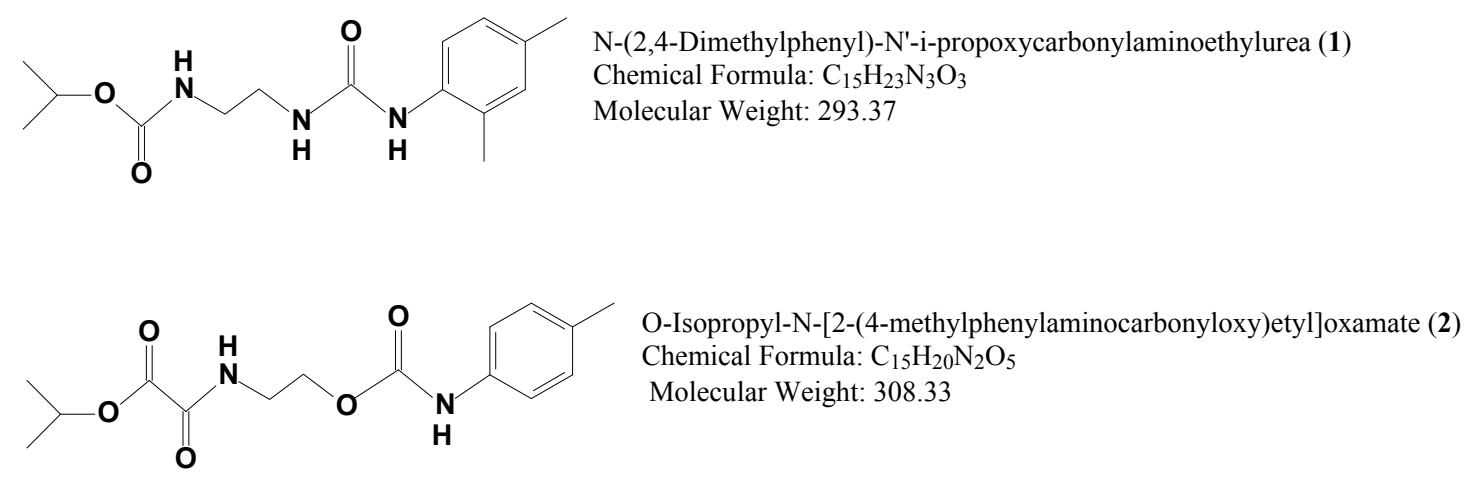<smiles>CC(C)OC(=O)NCCO</smiles>

O-i-Propyl-N-(2-hydroxyethylamino)carbamate (3)
Chemical Formula: $\mathrm{C}_{6} \mathrm{H}_{13} \mathrm{NO}_{3}$
Molecular Weight: 147.17<smiles>CC(C)OC(=O)C(=O)NCCO</smiles>

O-i-Propyl-N-(2-hydroxyethyl)oxamate (4) Chemical Formula: $\mathrm{C}_{7} \mathrm{H}_{13} \mathrm{NO}_{4}$ Molecular Weight: 175.18

Figure 1. Structure formulas of the compounds 1-4

Structures of all synthesized compounds were confirmed by ${ }^{1} \mathrm{H}$ and ${ }^{13} \mathrm{C}$ NMR, mass-spectrometry and elemental analysis data. ${ }^{1} \mathrm{H}$ and ${ }^{13} \mathrm{C}$ NMR-spectra were recorded with «Bruker DRX-400» spectrometer operating at 400.13 MHz frequency, using DMSO- $\mathrm{d}_{6}$ as solvent and TMS as an internal standard. Chemical shifts were measured with $0.01 \mathrm{ppm}$ accuracy; coupling constants are reported in Hertz. Mass-spectrawere recorded on an inductively coupled plasma mass spectrometer XSeries II ICP-MS (Thermo Scientific Inc., USA). The melting points were determined using the melting point (temperature) apparatus Stuart SMP20 (UK).

N-(2,4-Dimethylphenyl)-N'- $i$-propoxycarbonylaminoethylurea (1). A solution of $1.46 \mathrm{~g}(10 \mathrm{mM})$ of O-isopropyl-N-(2-aminoethyl)carbamate in $15 \mathrm{ml}$ of dry toluene was placed in a round bottom flask equipped with a calcium chloride tube and magnetic stirrer. Then solution of $1.47 \mathrm{~g}(10 \mathrm{mM})$ of 2,4-dimethylphenylisocyanate in dry toluene $(30 \mathrm{ml})$ and $2-3$ drops of triethylamine were added. The reaction mixture was stirred at room temperature for 15 minutes wherein precipitation was formed. The resulting precipitate was filtered off. The product was purified by recrystallization from $i$-propanol. The yield of title compound was 95\%, m.p. $=197-198{ }^{\circ} \mathrm{C} .{ }^{1} \mathrm{H}$ NMR (DMSO-d6, $\delta$, ppm, $J, \mathrm{~Hz}$ ): 1.16 [d, 6H, $\left.\mathrm{CH}_{3}-\mathrm{CH}, J=6.4\right]$; $2.13\left[\mathrm{~s}, 3 \mathrm{H}, p-\mathrm{CH}_{3}-\mathrm{Ph}\right] ; 2.20\left[\mathrm{~s}, 3 \mathrm{H}, \mathrm{o}-\mathrm{CH}_{3}-\mathrm{Ph}\right] ; 3.02-3.18$ [dm, $\left.4 \mathrm{H}, \mathrm{NH}-\mathrm{CH}_{2}, J=3.4\right] ; 3.45[\mathrm{~s}, 1 \mathrm{H}$, $\mathrm{NH}$-carbamate]; 4.76 [sept, $1 \mathrm{H}, \mathrm{CH}-\mathrm{O}-\mathrm{CO}, J=6.4] ; 6.50$ [s, $1 \mathrm{H}, \mathrm{NH}$, urea]; 6.85-6.96 [m, 2H, arom]; 7.03 [m, $1 \mathrm{H}, \mathrm{NH}$, urea]; 7.54-7.67 [m, 2H, arom]. ${ }^{13} \mathrm{C}$ NMR (DMSO-d 6 , $\left.\delta, \mathrm{ppm}\right): 18.28 ; 20.75 ; 22.55 ; 39.5 ; 41.27 ; 67.06$ (aliphatic C-O); 121.74; 126.91; 127.88; 129.45; 131.04; 131.34; 135.96; 156.15 (urea); 157.4 (carbamate). [M + $1]^{+} 294.42$; calculated values 294.37 .

O-Isopropyl-N-[2-(4-methylphenylaminocarbonyloxy)etyl]oxamate (2). A solution of $1.75 \mathrm{~g}(10 \mathrm{mM})$ of O-isopropyl-N-(2-hydroxyethyl)oxamatein $15 \mathrm{ml}$ of dry toluene was placed in a round bottom flask equipped with a calcium chloride tube and magnetic stirrer. Then solution of $1.47 \mathrm{~g}(10 \mathrm{mM})$ of 2,4-dimethylphenylisocyanate in dry toluene $(30 \mathrm{ml})$ and $2-3$ drops of triethylamine were added. The reaction mixture was stirred at room temperature for 15 minutes wherein precipitation was formed. The resulting precipitate was filtered off. The product was purified by recrystallization from $i$-propanol. The yield of title compound was 55\%, m.p. $=205-206{ }^{\circ} \mathrm{C} .{ }^{1} \mathrm{H}$ NMR (DMSO-d6, $\delta$, ppm, $\left.J, \mathrm{~Hz}\right): 0.91$ (d, 6H, $\mathrm{CH}_{3}, J=6.2$ ); 1.96 (sept, $1 \mathrm{H}, \mathrm{CHCH}_{3}, J=6.4$ ); 2.24 (s, $3 \mathrm{H}, \mathrm{CH}_{3} \mathrm{CH}$, arom); 3.45 (bs, $2 \mathrm{H}, \mathrm{CH}_{2} \mathrm{O}$ ); 3.99 (d, 2H, $\mathrm{CHCH}_{2} \mathrm{O}, J=6.2$ ); $4.18\left(\mathrm{t}, 2 \mathrm{H}, \mathrm{CH}_{2} \mathrm{NH}, J=5.0\right) ; 7.08(\mathrm{~d}, 2 \mathrm{H}, m-\mathrm{CH}$, arom, $J=7.7) ; 7.33$ (d, $2 \mathrm{H}, o-\mathrm{CH}$, arom, $\left.J=7.5\right) ; 9.04$ (bs, 1 $\mathrm{H}, \mathrm{NHCOO}) ; 9.57$ (bs, $1 \mathrm{H}, \mathrm{NHCOO}) .{ }^{13} \mathrm{C}$ NMR (DMSO-d $\left.6, \delta, \mathrm{ppm}\right): 19.18\left(\mathrm{CH}_{3}\right) ; 20.78\left(\mathrm{CH}_{3} \mathrm{C}\right) ; 27.58$ 
$\left(\mathrm{CHCH}_{3}\right) ; 54.67\left(\mathrm{CHCH}_{2} \mathrm{O}\right) ; 62.37\left(\mathrm{CH}_{2} \mathrm{NH}\right) ; 72.06\left(\mathrm{CH}_{2} \mathrm{O}\right) ; 118.69$ (aromatic C); 129.63 (aromatic $\mathrm{CH}$ ); 131.00 (aromatic $\mathrm{CH}) ; 136.94$ (aromatic ipso-C); $153.84(\mathrm{CONH}) ; 157.69(\mathrm{OCNH}) ; 161.04(\mathrm{OCO}) .[\mathrm{M}+1]^{+}$ 281.10; calculated values 281.14

Compounds 1 and 2 are insoluble in water and for their use in the experiments they were dissolved in dimethyl sulfoxide (DMSO), which is widely used in medicine. This procedure made it possible to create a stable colloidal suspension of the required concentration.

O-i-Propyl-N-(2-hydroxyethylamino)carbamate (3) was synthesized according to procedure describedbefore (Patent RU, 2020).

O-i-Propyl-N-(2-hydroxyethyl)oxamate (4). $9.74 \mathrm{~g}(67 \mathrm{mM})$ ofdiisopropyloxalate in ethanol (3.4 ml) was placed in a round bottom flask equipped with a dropping funnel and magnetic stirrer. The solution was cooled on an ice water bath up to $0{ }^{\circ} \mathrm{C}$. Then solution of $0.811 \mathrm{~g}(13.3 \mathrm{mmol})$ of the monoethanolamine in ethanol $(7 \mathrm{ml})$ was added dropwise to a stirred cool mixture. After the addition the mixture was left to warm up to room temperature, filtered and concentrated under vacuum. The product obtained was pure enoughfor further transformations, yield 90\%. ${ }^{1} \mathrm{H}$ NMR (DMSO-d6, $\delta$, ppm, $J, \mathrm{~Hz}$ ): 1.27 (d, 6H, $\mathrm{CH}_{3}, J^{3}=7.1$ ); 3.20-3.24 (m, 2H, NH-CH $) ; 3.47$ (t, 2H, $\left.\mathrm{CH}_{2} \mathrm{OH}, J^{3}=5.6\right) ; 4.20-4.26(\mathrm{~m}, 1 \mathrm{H}, \mathrm{CH}) .{ }^{13} \mathrm{C}$ NMR $\left(\mathrm{DMSO}-\mathrm{d}_{6}, \delta, \mathrm{ppm}\right): 21.54\left(\mathrm{CH}_{3}\right) ; 42.47\left(\mathrm{NH}-\mathrm{CH}_{2}\right) ; 61.25$ $\left(\mathrm{CH}_{2}-\mathrm{OH}\right) ; 71.65\left(\mathrm{CH}\left(\mathrm{CH}_{3}\right)_{2}\right) ; 157.62(\mathrm{O}-\mathrm{C}(\mathrm{O})) ; 159.98(\mathrm{C}(\mathrm{O})-\mathrm{NH})$.

Compounds 3 and 4 are highly soluble in water.

\subsection{Treatment and Experimental Design}

Wheat seeds (Triticum aestivum L.) were obtained from Biosphere LLC, Fedorovka village, Staroshaigovsky District, Mordovia, Russia. These seeds were in the registry of the Customs Union. The seeds are certified according to the safety requirements specified in the technical regulations of the Customs Union. In accordance with the Declaration EAEC NRUD-RU.AB97.V.0093/19, the seeds are named: "selected wheat for germination".

Seeds that were uniform in size and plump without damaging the embryo were carefully selected, disinfected for 10 min with $0.2 \%$ sodium hypochlorite solution to prevent microbial and fungal infections, and then washed three times with distilled water. Subsequently, the water on the surface of the wheat seeds was absorbed with filter paper, and then they were dried in an oven at $30^{\circ} \mathrm{C}$ for 48 hours. The dried seeds were stored at $5{ }^{\circ} \mathrm{C}$ in a refrigerator.

For comparison, we used Chlormequat chloride (CCC), as a plant growth regulator recommended by BASF for the CIS countries, Asia and Africa. CCC is designed to increase the mass of the root system; increase the resistance of plants to stress; increase the survival rate of productive shoots during the period of their further discharge; prevent root lodging. However, this is a chlorine containing salt and so one of the goals of the work is to replace this compound. Other plant growth regulators (N-[2-(2-oxo-l-imidazolidinyl) ethyI]-N'-plienylureaEDU, 1-phenyl-3-(1,2,3-thiadiazol-5-yl) urea-TDZ were used, but these studies were not included in the article, because these two compounds are not widely used in Russia.

Three independent series of experiments were conducted: two in Petri dishesand a "pot" experiment. All the experiments were conducted simultaneously in the same room on a Phyto-LED NLO-79-01-00unit, which provides 12-hour illumination of samples with an intensity of at least 250 lux (plus 12 hours of darkness) and Red 615/Blue $457 \mathrm{~nm}$ wavelengths at $65 \%$ relative humidity.

The germination rate was calculated according to Equation (1) proposed by the International Seed Testing Association (ISTA, 2017).

$$
\text { Germination } \%=\frac{\text { Number of Germinated Seeds }}{\text { Number of Total Seeds }} \times 100
$$

Relative water content (RWC) of wheat leaves was measured according to the Equation (2) (Mullan \& Pietragalla, 2018).

$$
\mathrm{RWC} \%=\frac{\mathrm{FW}-\mathrm{DW}}{\mathrm{TW}-\mathrm{DW}} \times 100
$$

Where, FW: fresh weight, TW: turgid weight, and DW: dry weightof the same sample.

Seedling Vigor Index (I) = SVI (I) was calculated using Equation (3), according to (Abdul-Baki \& Anderson, 1973):

$$
\text { SVI }(\mathrm{I})=\text { Germination Percentage } \times[\text { Root Length }(\mathrm{cm})+\text { Shoot Length }(\mathrm{cm})]
$$


Seedling Vigor Index (II) = SVI (II) was calculated using Equation (4), according to (Farahani et al., 2011; Marioufi et al., 2011):

$$
\text { SVI (II) }=\text { Dry Weight of Seedling }(\mathrm{mg}) \times \text { Germination Percentage }
$$

\subsubsection{The First Series of Experiments in Petri Dishes}

Dry wheat seeds were taken in the first series of experiments. For this, a round support of filter paper of the appropriate size was placed in the cups and 50 seeds were spread over its surface; the seeds were pretreated with pump irrigation with dilute aqueous solutions of compounds $1-4$ in a ratio of $10 \mathrm{mg} \mathrm{L}^{-1}$. After that 50 dry seeds were germinated in Petri dishes with a threefold repetition of the experiment. Pump spraying was carried out in an insulated box, the surface of which, at the end of the procedure, was disinfected with steam and wiped with paper napkins. After spraying, the seeds were covered with filter paper of the appropriate diameter and filled with $10 \mathrm{ml}$ of distilled water. Then Petri dishes with lids were placed on the shelves of the germinating device at $20{ }^{\circ} \mathrm{C}$ for 7 days. The first control group of seeds was treated with pump spray with distilled water, the second, with CCC with a concentration of $10 \mathrm{mg} \mathrm{L}^{-1}$. Petri dishes with seeds were aired daily for 25 minutes by removing the lids, and, if necessary, $5-10 \mathrm{ml}$ of distilled water was added to prevent the seeds from drying out.

On the third day of germination, the lids were removed from the Petri dishes so as not to interfere with the growth of seedlings. On the 7th day, according to the Formula (1), seed germination was determined. To measure the length of the root (RL) and shoot (SL), 15 seedlings were randomly selected from each Petri dish. In addition, RWC, SVI (I) and SVI (II) were calculated using Equations (2), (3) and (4), respectively. The measurement results are presented in Table 1 and Figures 2-6.

\subsubsection{The Second Series of Experiments in Petri Dishes}

In the second series of experiments about 320 wheat seeds were steeped in distilled water for 18 hours. After this period, the seeds were distributed between six Petri dishes. As a criterion of germination, the root of $1 \mathrm{~mm}$ was registered. Pump irrigation was performed as described in 2.2.1. A total of six procedures were conducted, each one repeated four times, so totally 24 Petri dishes were included in this study. Germination rate, RWC, SVI (I) and SVI (II) were calculated in the same way as in 2.2.1. The measurement results are presented in Table 2 and Figures 2-6, which also demonstrate a significant effect of compounds 1-4 on the germination of presoaked wheat seeds and the length of 7-day old seedlings.

\subsubsection{The Third Series of Experiments in Garden Soil}

Wheat seeds were sown in twelve 9-cell $(4 \times 5 \times 6 \mathrm{~cm})$ plastic cassettes $(18 \times 14 \times 6 \mathrm{~cm})$ containing universal garden soil, which was classified as universal garden soil containing garden compost $(60 \%)$, peat $(30 \%)$, and quartz sand (10\%) with the following characteristics: $\mathrm{pH}$ in $\mathrm{H}_{2} \mathrm{O}$ of 5.5-6.5; less than $30 \%$ of organic matter; less than $20 \mathrm{mg} \mathrm{dm}^{-3}$ of P; $0.35 \mathrm{mg} \mathrm{dm}^{-3}$ of K; $1.8 \mathrm{mg} \mathrm{dm}^{-3}$ of N; humidity no more $50 \%$.

For this purpose, dry wheat seeds were placed in Petri dishes, 50 pieces per each. Spraying was performed as described in 2.2.1. Then the treated seeds were transferred into plastic pots with a pre-moistened soil, sprinkled with soil and left for germination on a phyto-LED lighting unit providing illumination of samples 12 hours a day at $20^{\circ} \mathrm{C}$. Seeds sprayed with distilled water and placed in plastic pots were chosen as the first control group. The second control group of seeds in a Petri dish was treated by spraying CCC with concentration of $10 \mathrm{mg} \mathrm{L}^{-1}$. Then the seeds were also transferred into plastic pots. In total, six procedures were performed; each procedure was repeated three times. Two weeks after the start of the third series of experiments, the watering regime of the plants was suspended for seven days. The duration of this experiment was 30 days. Germination, RWC, SVI (I) and SVI (II) were calculated in the same way as in paragraph 2.2.1. The measurement results are shown in Tables 3-5.

\subsection{Statistical Analysis}

Statistical processing of the results was performed using Microsoft Excel software and STATISTICA 13.3 TRIAL (StatSoft Russia). Basic statistical parameters such as mean, standard deviation (SD) were computed along with one-way analysis of variance (ANOVA). To assess the statistical significance of various data sets, an acceptable value of significance was $p \leq 0.05$. The $95 \%$ confidence interval of true averages is shown in the Tables 1-3.

\section{Results and Discussion}

\subsection{Seed Germination}

In the present study, we observed that for all the tested compounds 1-4 in the first and second series of experiments (Tables 1 and 2; Figure 2), there was a significant increase in germination results. The active ingredients softened the shell of wheat seeds, penetrated into the grain and activated physiological processes. This had a beneficial effect on their germination. Thus, the highest germination rate (89.6-96.3\%) was registered 
for compound 4, in the samples treated with compound 3, 81.3 and 95.1\%, respectively, while the lowest value was registered for CCC control substance $(67.2 \%)$, and in its in water and ease of penetration through cell membranes.

Table 1. Wheat (Triticum aestivum L.) reaction to compounds 1-4 on the first series of experiments in Petri dishes with dry wheat seeds

\begin{tabular}{llllllllll}
\hline Compound & $\mathrm{G}, \%$ & $\mathrm{RL}, \mathrm{cm}$ & $\mathrm{SL}, \mathrm{cm}$ & $\mathrm{FW}, \mathrm{mg}$ & $\mathrm{TW}, \mathrm{mg}$ & $\mathrm{DW}, \mathrm{mg}$ & $\mathrm{RWC}, \%$ & SVI (I) & SVI (II) \\
\hline Untreated $\left(\mathrm{H}_{2} \mathrm{O}\right)$ & $61.1^{\mathrm{ns}}$ & $3.9^{* *}$ & $5.7^{\mathrm{ns}}$ & $260^{\mathrm{ns}}$ & $380^{\mathrm{ns}}$ & $74^{*}$ & $60.78^{*}$ & $352.17^{*}$ & $4521.40^{\mathrm{ns}}$ \\
1 & $85.5^{* *}$ & $6.2^{*}$ & $6.3^{*}$ & $270^{* *}$ & $380^{* *}$ & $75^{*}$ & $63.93^{*}$ & $544.85^{* *}$ & $6412.50^{*}$ \\
2 & $89.6^{* *}$ & $5.1^{*}$ & $5.2^{* *}$ & $280^{* *}$ & $380^{\mathrm{ns}}$ & $75^{\mathrm{ns}}$ & $64.35^{\mathrm{ns}}$ & $471.02^{* *}$ & $6720.00^{* *}$ \\
3 & $81.3^{*}$ & $6.7^{*}$ & $10.1^{*}$ & $300^{*}$ & $400^{*}$ & $80^{*}$ & $68.75^{*}$ & $827.83^{*}$ & $6504.00^{*}$ \\
4 & $89.6^{*}$ & $8.8^{*}$ & $10.8^{*}$ & $290^{*}$ & $400^{*}$ & $80^{*}$ & $65.62^{\mathrm{ns}}$ & $976.48^{*}$ & $7168.00^{*}$ \\
$\mathrm{CCC}$ & $67.2^{*}$ & $6.3^{*}$ & $7.4^{*}$ & $270^{*}$ & $390^{\mathrm{ns}}$ & $78^{\mathrm{ns}}$ & $61.53^{\mathrm{ns}}$ & $503.58^{* *}$ & $5241.60^{*}$ \\
\hline
\end{tabular}

Note. G: germination; RL: root length; SL: shoot length; FW: fresh weight; TW: turgid weight; DW: dry weight; RWC: relative water content; SVI (I): seedling vigor index; SVI (II): seedling vigor index.

$*$ significant at $5 \%$ and at ** $1 \%$ probability; ns = not significant according to the $\mathrm{F}$ test.

Table 2. Wheat (Triticum aestivum L.) reaction to compounds 1-4 on the second series of experiments in Petri dishes with wheat seeds

\begin{tabular}{llllllllll}
\hline Compound & $\mathrm{G}, \%$ & $\mathrm{RL}, \mathrm{cm}$ & $\mathrm{SL}, \mathrm{cm}$ & $\mathrm{FW}, \mathrm{mg}$ & $\mathrm{TW}, \mathrm{mg}$ & $\mathrm{DW}, \mathrm{mg}$ & $\mathrm{RWC}, \%$ & SVI (I) & SVI (II) \\
\hline Untreated $\left(\mathrm{H}_{2} \mathrm{O}\right)$ & $87.0^{\mathrm{ns}}$ & $5.7^{\mathrm{ns}}$ & $6.5^{\mathrm{ns}}$ & $270^{\mathrm{ns}}$ & $390^{\mathrm{ns}}$ & $75^{*}$ & $66.39^{*}$ & $571.20^{\mathrm{ns}}$ & $6525.00^{\mathrm{ns}}$ \\
1 & $94.4^{* *}$ & $6.2^{*}$ & $7.5^{*}$ & $280^{*}$ & $370^{*}$ & $74^{*}$ & $69.59^{\mathrm{ns}}$ & $714.20^{*}$ & $6985.60^{*}$ \\
2 & $88.8^{*}$ & $5.0^{*}$ & $5.6^{\mathrm{ns}}$ & $310^{*}$ & $390^{*}$ & $75 \mathrm{~ns}$ & $74.60^{\mathrm{ns}}$ & $941.28^{*}$ & $6660.00^{\mathrm{ns}}$ \\
3 & $95.1^{*}$ & $* 5.7^{*}$ & $11.2^{\mathrm{ns}}$ & $300^{*}$ & $490^{*}$ & $79^{*}$ & $71.06^{* *}$ & $1070.82^{*}$ & $7512.90^{\mathrm{ns}}$ \\
4 & $96.3^{*}$ & $5.8^{*}$ & $12.7^{*}$ & $310^{*}$ & $390^{*}$ & $80^{* *}$ & $74.27^{*}$ & $1228.81^{*}$ & $7704.0^{*}$ \\
CCC & $92.5^{*}$ & $6.4^{*}$ & $7.5^{*}$ & $280^{*}$ & $380^{*}$ & $78^{\mathrm{ns}}$ & $67.10^{\mathrm{ns}}$ & $700.15^{* *}$ & $7215.00^{*}$ \\
\hline
\end{tabular}

Note. G: germination; RL: root length; SL: shoot length; FW: fresh weight; TW: turgid weight; DW: dry weight; RWC: relative water content; SVI (I): seedling vigor index; SVI (II): seedling vigor index.

$*$ significant at $5 \%$ and at ** $1 \%$ probability; ns = not significant according to the $\mathrm{F}$ test.

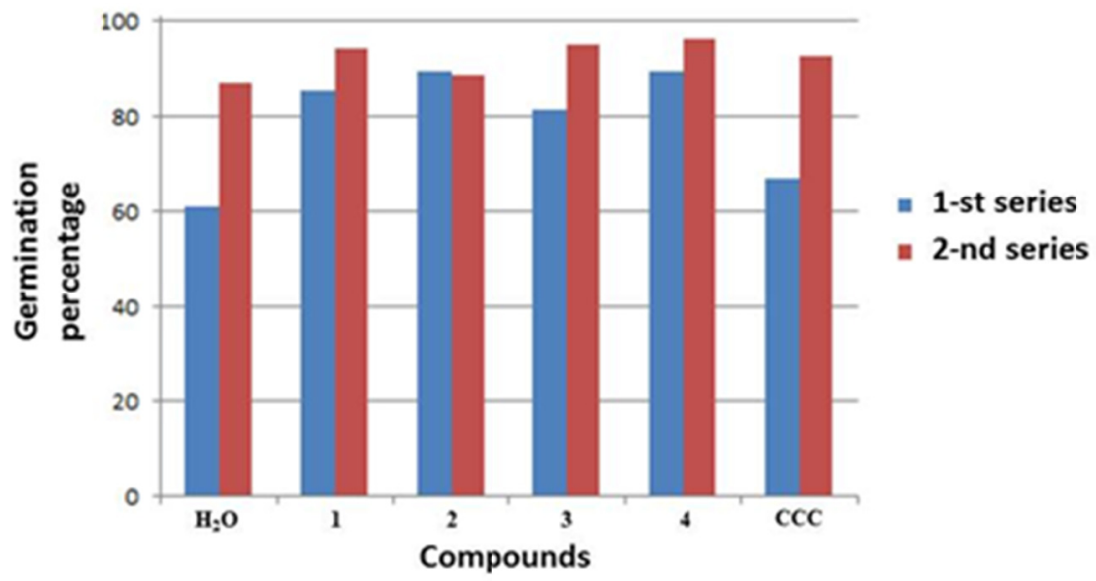

Figure 2. Seed germination for experiments of the first and second series of the studied compounds

\subsection{Length of Root and Shoot}

A strong stimulating effect on the growth of shoots and roots of wheat was found for all studied compounds in all experiments (Tables 1 and 2; Figure 3), and the best results were obtained for compounds 3 and 4 . Plants treated with compounds 3 and 4 had a higher shoots, than control plants. Plant heights of $72-78 \%$ for compound 
3 and $89-95 \%$ for compound 4 were higher than plants in the first control group and 36-49\% for compound 3 and $45-69 \%$ for compound 4, plague in the second control group. This is due to the fact that compounds 3 and 4 are derivatives of Cartolin-2, which in small doses affects the growth and metabolism of cells of higher plants, inhibits the destruction of chloroplasts, and increases the activity of RNA-polymerase does not affect transpiration, which is a characteristic indicator of the hormonal action of cytokines (Baskakov et al., 1982; Zhirmunskaya et al., 1989).

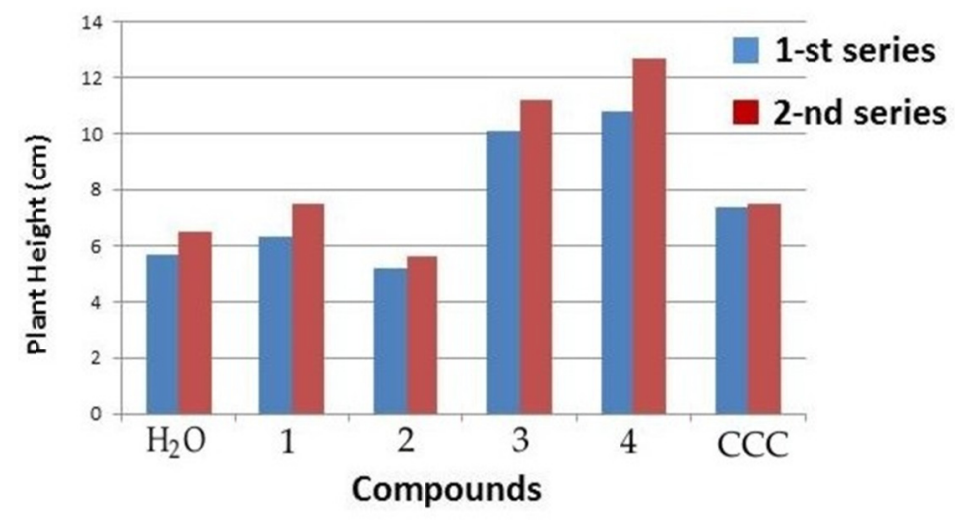

Figure 3. Plant height for experiments of the first and second series of the studied compounds

\subsection{Relative Water Content (RWC)}

It is known that lack of water leads to the restriction of photosynthesis as a result of closure of the stomata; as a consequence, there is a delay in growth, which leads to a dry biomass and a decrease in height (Ghotbi-Ravandi et al., 2014). Measuring leaf relative water content is a reliable and simple way to assess the water status of a leaf without any need for special equipment. Similar to leaf water potential, leaf RWC gives a strong indication of the plant's response to different environmental conditions; and it has been shown that RWC is a more stable parameter than leaf water potential (Sade et al., 2015). The relative water content (RWC; or "relative plumpness") of a leaf is a measurement of its hydration (actual water content) in relation to its maximum water holding capacity. The RWC provides a measure of leaf "water deficit" and can indicate a degree of stress expressed in drought and heat stress conditions. Typical values of RWC range between $98 \%$ in turgid and transpiring leaves to about $40 \%$ in severely desiccated and senescing leaves; leaf RWC at wilting is around $60-70 \%$ (Mullan \& Pietragalla, 2018).

At the time of the end of the 1-st and 2-nd series of experiments, the RWC of leaves lies in the range of $60-70 \%$ (Tables 1 and 2; Figure 4). This means that the leaves of all plants are in a period of wilting, and only additional research can prove that they can tolerate adiabatic stress.

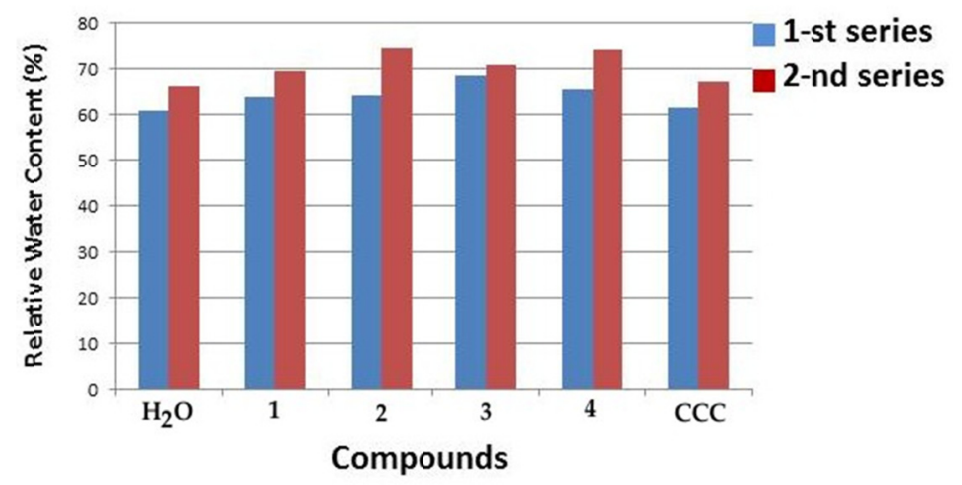

Figure 4. Relative Water Content for experiments of the first and second series of the studied compounds 


\subsection{Seedling Vigor Index (SVI)}

Seed vigour is an important component of seed quality and ISTA congress adopted the definition of seed vigour as "the sum total of those properties of the seed which determine the level of activity and performance of the seed or seed lot during germination and seedling emergence" (Gupta, 1993). The seed lot showing the higher seed vigour index is considered to be more vigorous" (Abdul-Baki \& Anderson, 1973).

Using compounds 1, 3 and 4 in all cases leads to a significant increase in the Seedling Vigor Index, which is presented in Tables 1-3; Figures 5 and 6. The highest energy index was registered for the compounds 4 both SVI values (I and II) for the first (976 and 7168) and for the second (1228.81 and 7704.00) and, according to this, in the third series of experiments (3798.49 and 5133.10). The lowest were 503.58 and 4850.70 for the second control group. High energy index, especially for compounds 3 and 4, may lead to an intensification of photosynthesis and consequently to an increase in productivity (Dhinesh et al., 2010).

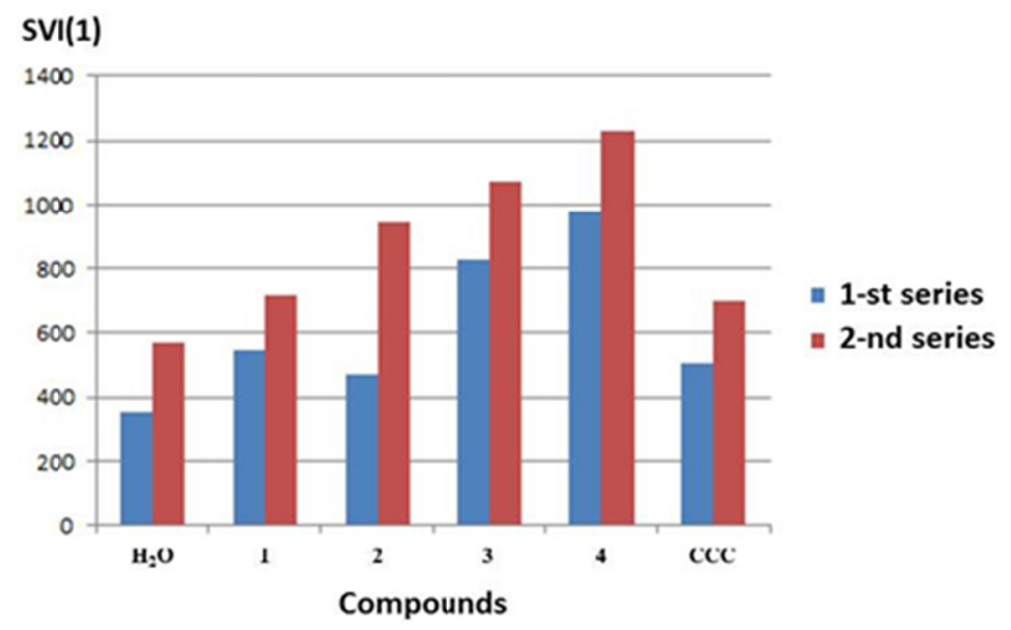

Figure 5. Seeding Vigor Index (SVI (I)) for experiments of the first and second series of the studied compounds

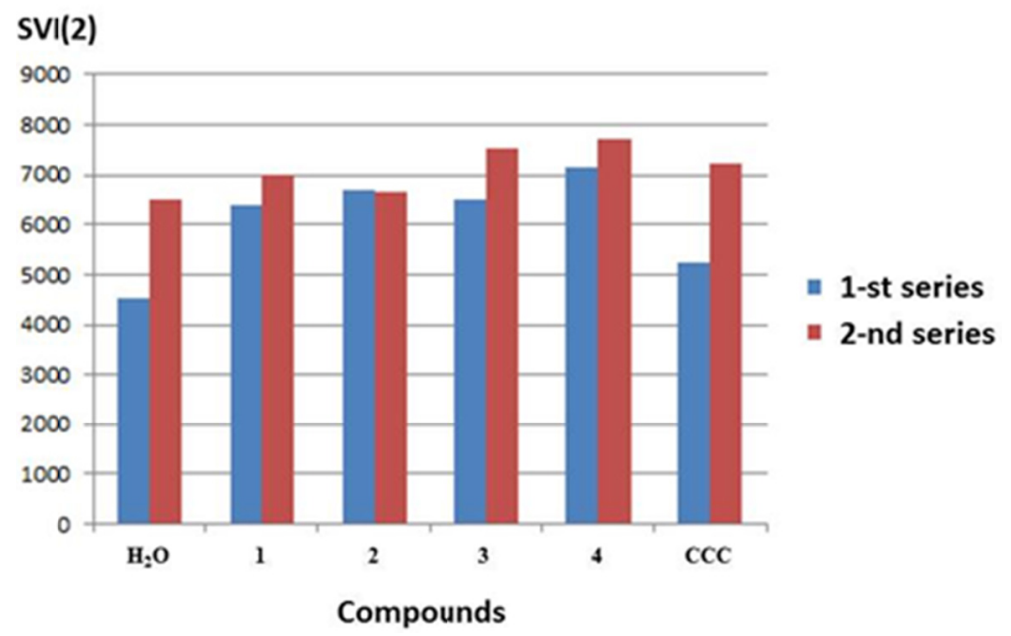

Figure 6. Seeding Vigor Index (SVI (II)) for experiments of the first and second series of the studied compounds 
Table 3. Wheat (Triticum aestivum L.) reaction to compounds 1-4 on the third series of experiments in garden soil

\begin{tabular}{llllllllll}
\hline Compound & $\mathrm{G}, \%$ & $\mathrm{RL}, \mathrm{cm}$ & $\mathrm{SL}, \mathrm{cm}$ & $\mathrm{FW}, \mathrm{mg}$ & $\mathrm{TW}, \mathrm{mg}$ & $\mathrm{DW}, \mathrm{mg}$ & $\mathrm{RWC}, \%$ & $\mathrm{SVI}(\mathrm{I})$ & SVI (II) \\
\hline Untreated $\left(\mathrm{H}_{2} \mathrm{O}\right)$ & $66.6^{\mathrm{ns}}$ & $13.4^{\mathrm{ns}}$ & $28.7^{\mathrm{ns}}$ & $595^{\mathrm{ns}}$ & $708^{\mathrm{ns}}$ & $61^{*}$ & $82.59^{*}$ & $2806.38^{\mathrm{ns}}$ & $4066.26^{\mathrm{ns}}$ \\
1 & $65.9^{*}$ & $15.1^{*}$ & $34.3^{*}$ & $664^{*}$ & $790^{* *}$ & $72^{\mathrm{ns}}$ & $82.45^{* *}$ & $3259.41^{*}$ & $4750.56^{*}$ \\
2 & $57.4^{*}$ & $14.4^{*}$ & $32.4^{*}$ & $667^{*}$ & $793^{*}$ & $72^{\mathrm{ns}}$ & $82.50^{* *}$ & $2686.78^{*}$ & $4133.52^{*}$ \\
3 & $64.8^{*}$ & $15.0^{*}$ & $34.2^{*}$ & $665^{*}$ & $791^{* *}$ & $71^{* *}$ & $82.50^{* *}$ & $3188.65^{*}$ & $4661.51^{*}$ \\
4 & $73.3^{*}$ & $17.0^{*}$ & $34.8^{*}$ & $645^{*}$ & $767^{* *}$ & $70^{\mathrm{ns}}$ & $82.49^{* *}$ & $3798.49^{*}$ & $5133.10^{*}$ \\
$\mathrm{CCC}$ & $70.0^{*}$ & $13.0^{* *}$ & $29.9^{*}$ & $643^{* *}$ & $765^{\mathrm{ns}}$ & $69^{* *}$ & $82.47^{* *}$ & $2952.60^{* *}$ & $4850.70^{*}$ \\
\hline
\end{tabular}

Note. G: germination; RL: root length; SL: shoot length; FW: fresh weight; TW: turgid weight; DW: dry weight; RWC: relative water content; SVI (I): seedling vigor index; SVI (II): seedling vigor index.

$*$ significant at $5 \%$ and $* *$ at $1 \%$ probability; $\mathrm{ns}=$ not significant according to the $\mathrm{F}$ test.

\subsection{Results of the Third Series of Soil Experiments}

Seed germination was determined on the tenth day after the start of the experiment and was calculated using the Formula (1). The germination of seeds treated with compound 4 was $10 \%$ higher than that of the first control group and 4\% higher than that of the second control group (Table 3). Two weeks after the start of the third series of experiments, the watering regime of the plants was suspended for seven days (Table 4, column 1). The following column shows the appearance of the shoots on the 7-th day after the cease of irrigation of the plants (Table 4, column 2). Resumption of the irrigation regime leads to partial (for compounds 1 and 2) or complete regeneration for compounds CCC and 3, 4 (Table 4, column 3).

Table 4. Results of experiments with stopping irrigation and regeneration after lodging

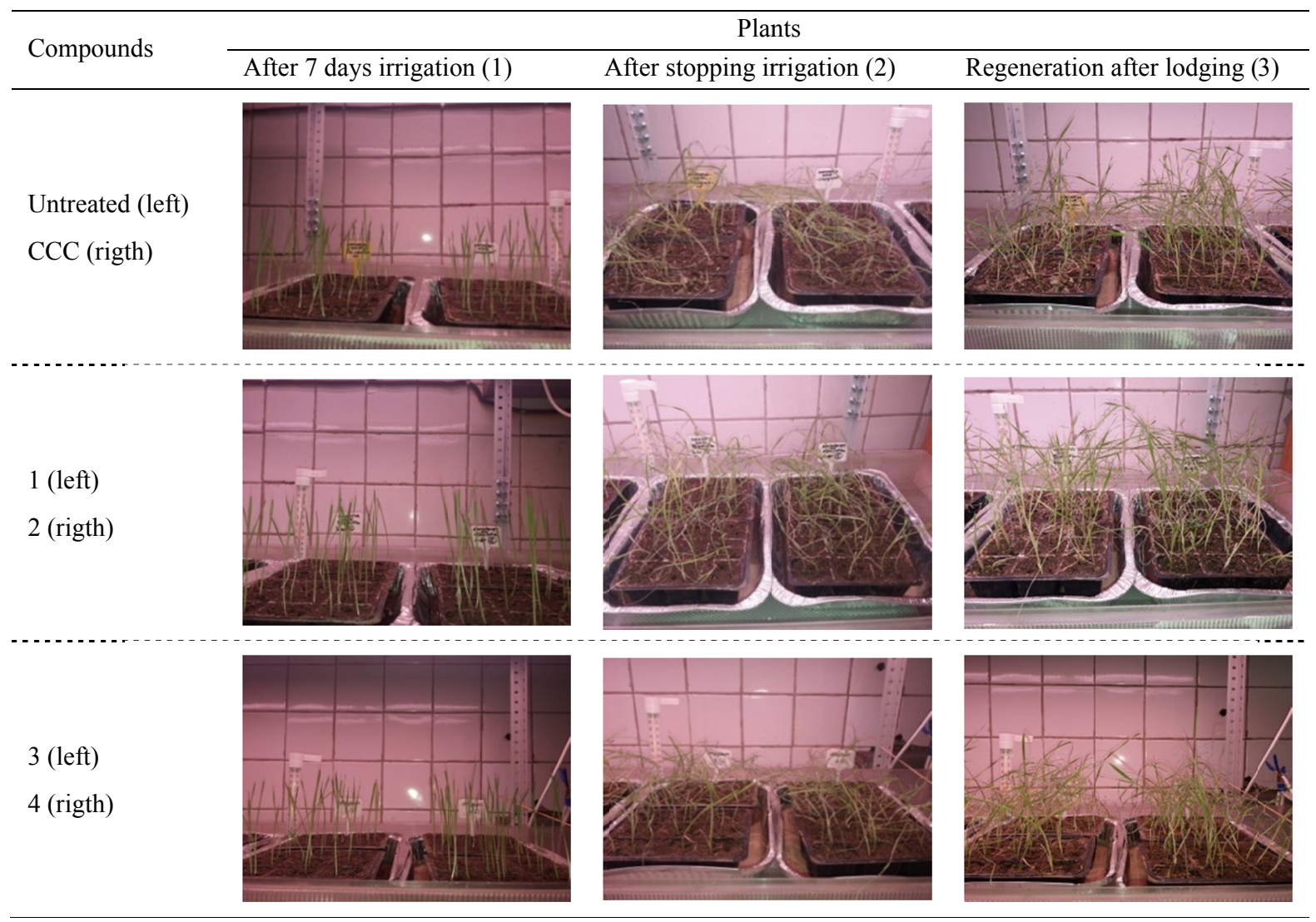

The following Table 5 shows data on the number of withered dead and surviving plants. Thus, the experimental results show that the percentage of plant regeneration after repeated irrigation was $84-100 \%$ in relation to the 
percentage of germination. When using compounds 1 and 2, some of the plants did not recover and died, although less than in the absence of any treatment. The best results were demonstrated for plants treated with substances CCC and 4 in the complete absence of withered plants, as well as for compound 3 .

Table 5. Plants regeneration after repeated irrigation

\begin{tabular}{lllllll}
\hline Compound & Untreated & 1 & 2 & 3 & 4 & CCC \\
\hline Number of withered plants & 10 & 7 & 8 & 1 & 0 & 0 \\
Restored plants, \% & 80 & 86 & 84 & 98 & 100 & 100 \\
\hline
\end{tabular}

The length of the root and shoots was determined at the time of the end of the experiment. Plants treated with compounds 1,3 and 4 were $21 \%$ higher than those of the first control group and $17 \%$ higher than the plants of the second control group (Table 3). The relative water content (RWC) was $82 \pm 10 \%$ in all plants at the end of the third series of experiments. This indicates that all samples survived a water deficit.

\section{Conclusion}

The data obtained as a result of biological tests indicate that the synthesized compounds 1-4 with functional groups separated by ethylene spacer are characterized by the expressed antistress and growth regulatory activity. The active substances softened the shell of wheat seeds, penetrated into the grain and activated physiological processes, which subsequently had a beneficial effect on their germination. Their use result in a significant increase of germination, an increase in the index of plant viability, it has a stimulating effect on the growth of shoots and roots in this wheat variety, as well as it improves resistance to water stress and the formation of dry matter. Plants treated with compounds 3 and 4 further improve their ability to fully regenerate after lodging as a result of a weekly drought. Thus, the obtained new synthetic antistress drugs increase the resistance of wheat plants (Triticum aestivum L.) to negative environmental factors and exhibit growth regulating activity.

\section{References}

Abdul-Baki, A. A., \& Anderson, J. D. (1973). Vigor Determination in Soybean Seed by Multiple Criteria. Crop Sci., 13(6), 630-633. https://doi.org/10.2135/cropsci1973.0011183X001300060013x

Asseng, S., Ewert, F., Martre, P., Rötter, R. P., Lobell, D., Cammarano, D., ... White, J. W. (2015). Rising temperatures reduce global wheat production. Nature Clim. Chan., 5, 143-147. https://doi.org/10.1038/ nclimate 2470

Barlow, K., Christy, B., O’Leary, G., Riffkin, P., \& Nuttall, J. (2015). Simulating the impact of extreme heat and frost eventson wheat crop production: A review. Field Crop. Res., 171, 109-119. https://doi.org/ 10.1016/j.fcr.2014.11.010

Baskakov, U. A., Zhirmunskaya, N. M., Shapovalov, A. A., \& Ovsyannikova, T. V. (1982). Comparative study of the growth-regulating activity of synthetic and natural cytokinins. Agricult. Chem., 8, 124-129.

Brinkman, J. M. P., Deen, W., Lauzon, J. D., \& Hooker, D. C. (2014). Synergism of Nitrogen Rate and Foliar Fungicides in Soft Red Winter Wheat. Agronomy, 106(2), 491-510. https://doi.org/10.2134/agronj2013.0395

Bystrova, N. A. (2020). Science education activity of the A. N. Nesmeyanov Institute of Organoelement Compounds, Russian Academy of Sciences. Russ. Chem. Bull., 69(6), 1199-1202. https://doi.org/10.1007/ s11172-020-2891-7

Chauhan, A., Abuamarah, B., Kumar, A., Verma, J. S., Ghramh, H. A., Khan, K. A., \& Ansari, M. J. (2019). Influence of Gibberellic Acid and Different Salt Concentrations on Germination Percentage and Physiological Parameters of Oat Cultivars. Saudi J. Biol. Sci., 26, 1298-1304. https://doi.org/10.1016/ j.sjbs.2019.04.014

Dhankher, O. P., \& Foyer, C. H. (2018). Climate resilient crops for improving global food security and safety. Plant, Cell \& Environment, 41, 877-884. https://doi.org/10.1111/pce.13207

Dhinesh, B. K., Patel, R. K., Singh, A., Yadav, D. S., Le, L. C., \& Deka, B. C. (2010). Seed germination, seedling growth and vigour of papaya under North East India conditions. Acta Hort., 851, 229-306. https://doi.org/10.17660/ActaHortic.2010.851.46

FAOSTAT. (2017). Retrieved August 2, 2017, from http://www.fao.org/faostat/en/\#data 
Farahani, H. A., \& Maroufi, K. (2011). Effect of Hydropriming on Seedling Vigour in Basil (Ocimum Basilicun L.) under Salinity Conditions. Adv. Environ. Biol., 5(5), 828-833.

Finch, H. J. S., Samuel, A. M., \& Lane, G. P. F. (2014). Lockhart \& Wiseman's Crop Husbandry Including Grassland (pp. 287-336). Woodhead Publishing. https://doi.org/10.1016/C2013-0-23267-0

Ghotbi-Ravandi, A. A., Shahbazi, M., Shariati, M., \& Mulo, P. (2014). Effects of Mild and Severe Drought Stress on Photosynthetic Efficiency in Tolerant and Susceptible Barley (Hordeumvulgare L.) Genotypes. J. Crop Sci., 200, 403-415. https://doi.org/10.1111/jac.12062

Gupta, P. C. (1993). Seed vigour testing. In P. K. Agrawal (Ed.), Handbook of seed testing (pp. 242-249). DAC, Ministry of Agriculture, Govt. of India, New Delhi.

Hatfield, J. L., \& Prueger, J. H. (2015). Temperature extremes: Effect on plant growth and Development. Weath. Clim. Extrem., 10, 4-10. https://doi.org/10.1016/j.wace.2015.08.001

ISTA. (2017). International Rules for Seed Testing. Bassersdorf, CH, Switzerland.

Ito, R., Vasconcelos, H. L., \& Feeley, K. J. (2018). Global climate change increases risk of crop yield losses and food insecurity in the tropical Andes. Glob. Chan Biol., 24, 592-602. https://doi.org/10.1111/gcb.13959

Kovalenko, L. V., Kalistratova, A. V., Oshchepkov, M. S., Solovieva, I. N., Polivanova, A. G., Bystrova, N. A., \& Kochetkov, K. A. (2020). Biological activity of the novel plant growth regulators: N-Alkoxycarbonylaminoethyl-N'-arylureas. Bulg. J. Agric. Science, 26(4), 772-776.

Lukatkin, A. S., \& Kashtanova, N. N. (2013). Effect of thidiazuron on the thermal resistance of maize Seedlings. Proceed. Karelian Sci. Cent. Russ. Acad. Sci., 3, 129-135.

Marioufi, K., Farahani, H. A., \& Moradi, O. (2011). Thermo Priming Influence on Seeding Production in Wheat (Triticum Aestivum L.). Adv. Envir. Biology, 5(11), 3664-3667.

Mullan, D., \& Pietragalla, J. (2018). Physiological Breeding II: A Field Guide to Wheat Phenotyping. In A. Pask, J. Pietragalla, D. Mullan, \& M. Reynolds (Eds.), Physiological Breeding II (p. 25). The International Maize and Wheat Improvement Center, CIMMYT. Retrieved from https://plantstomata.wordpress.com/2018/01/ $30 / 66106$

Oshchepkov, M. S., Kalistratova, A. V., Savelieva, E. M., Romanov, G. A., Bystrova, N. A., \& Kochetkov, K. A. (2020). Natural and synthetic cytokinins and their applications in biotechnology, agrochemistry and medicine. Russ. Chem. Rev., 89(8), 787-810. https://doi.org/10.1070/RCR4921

Patent RU. (2020). Patent RU 2710939 C1.

Patent SU. (1992). Patent SU 1707015 A1.

Peltonen-Sainio, P., Jauhiainen, L., \& Latukka, A. (2020). Interactive tool or farmers to diversify high-latitudece real-dominated croprotation. Int. J. Agric. Sustain Ability, 18(4), 319-333. https://doi.org/10.1080/ 14735903.2020.1775931

Raza, A., Razzaq, A., Mehmood, S. S., Zou, X., Zhang, X., Lv, Y., \& Xu, J. (2019). Impact of Climate Change on Crops Adaptation and Strategies to Tackle Its Outcome: A Review. Plant, 8(2), 34. https://doi.org/ $10.3390 /$ plants 8020034

Razina, A. A., Dyatlova, O. G., Ryabchinskaya, T. A., \& Bobreshova, I. Yu. (2018). Efficiency of Biological Plant Growth Stimulator Stimmunol EF on Spring Wheat. Agricult. Chem., 7, 50-56. https://doi.org/ 10.1134/S0002188118070104

Rogelj, J., Elze, M., Höhn, N., Fransen, T., Fekete, H., Winkler, H., ... Meinshausen, M. (2016). Paris Agreement climate proposals need a boost to keep warming well below $2{ }^{\circ} \mathrm{C}$. Nature, 534, 631-639. https://doi.org/10.1038/nature18307

Sade, N., Galkin, E., \& Moshelion, M. (2015). Measuring Arabidopsis, Tomato and Barley Leaf Relative Water Content (RWC). BioProtocol., 5(8), 1451-1462. https://doi.org/10.21769/BioProtoc.1451

Salehi-Lisar, S. Y., \& Bakhshayeshan-Agdam, H. (2016). Drought Stress in Plants: Causes, Consequences, and Tolerance. Drought Stress Tolerance in Plants, 1, 1-16. https://doi.org/10.1007/978-3-319-28899-4_1

Shapovalov, A. A., \& Zubkova, N. F. (2003). Domestic growth regulators are growing. Agricult. Chem., 11, 33-47. https://doi.org/10.12731/wsd-2018-1-124-135 
Sosnowski, J., Malinowska, E., Jankowski, K., Król, J., \& Redzik, P. (2017). An estimation of the effects of synthetic auxin and cytokinin and the time of their application on some morphological and physiological characteristics of Medicago x varia T. Martyn. Saudi J. Biol. Sci., 26(1), 66-73. https://doi.org/ 10.1016/j.sjbs.2016.12.023

Tebaldi, C., \& Lobell, D. (2018). Estimated impacts of emission reductions on wheat and maize crops. Clim. Chan., 146, 533-545. https://doi.org/10.1007/s10584-015-1537-5

Thornton, P. K., Ericksen, P. J., Herrero, M., \& Challinor, A. J. (2014). Limate variability and vulnerability to climate change: A review. Glob. Chan. Biol., 20, 3313-3328. https://doi.org/10.1111/gcb.12581

Zhirmunskaya, N. M., Ovsyannikova, T. V., Shapovalov, A. A., \& Baskakov, U. A. (1989). The relationship between antistress activity and cytokinin-like properties of synthetic biologically active substances. Physiol. Biochem. Cult. Plants, 21(5), 446-459.

\section{Appendix A}

\section{Graphical Abstracts}

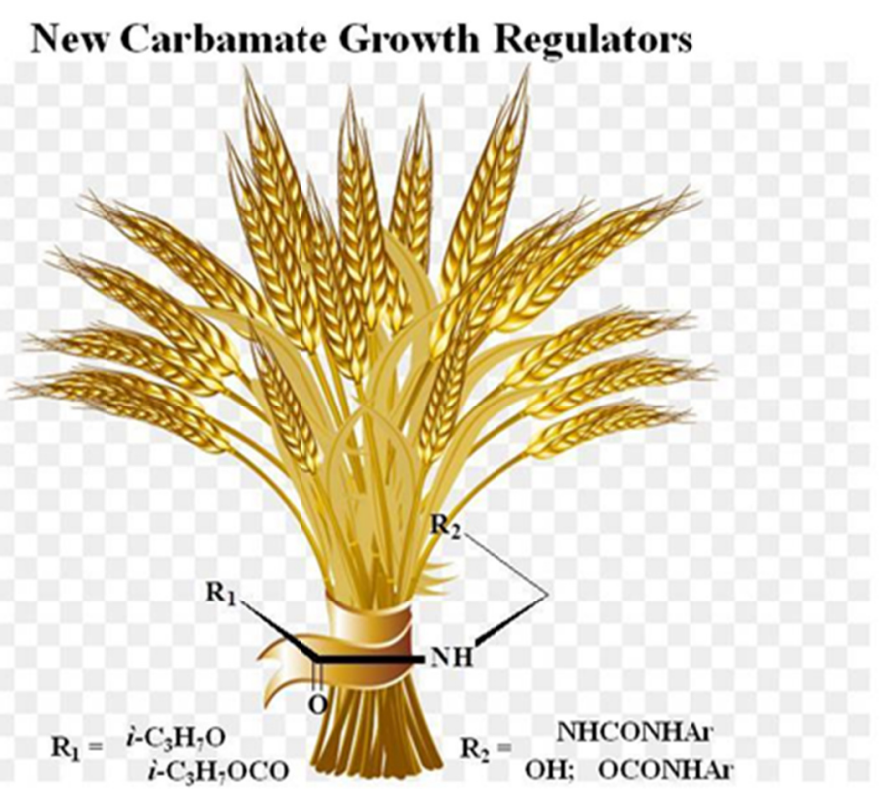

\section{Copyrights}

Copyright for this article is retained by the author(s), with first publication rights granted to the journal.

This is an open-access article distributed under the terms and conditions of the Creative Commons Attribution license (http://creativecommons.org/licenses/by/4.0/). 